\title{
Tools and Strategy for Distance Learning to Respond COVID-19 Pandemic in Indonesia
}

\author{
Muhammad Nur Yasir Utomo ${ }^{1 *}$, Memet Sudaryanto ${ }^{2}$, Kundharu Saddhono ${ }^{2}$ \\ ${ }^{1}$ Computer and Network Engineering Study Program, Department of Electrical Engineering, Politeknik Negeri Ujung \\ Pandang, Makassar 90245, Indonesia \\ ${ }^{2}$ Graduate School of Javanese Language and Literature, Faculty of Teacher and Training, Universitas Sebelas Maret, Surakarta \\ 57126, Indonesia
}

Corresponding Author Email: yasirutomo@poliupg.ac.id

https://doi.org/10.18280/isi.250314

Received: 7 March 2020

Accepted: 2 May 2020

\section{Keywords:}

distance learning, online learning, pandemic, COVID-19, distance learning tools

\begin{abstract}
Distance learning is a learning process that allows students and instructors are in different physical locations. During the COVID-19 pandemic, various countries including Indonesia chose the distance learning option to avoid the spread of the pandemic. However, the implementation of distance learning is not without problems. In Indonesia, the problems to implement distance learning are enormous both in terms of equitable distribution of infrastructure and costs for accessing the internet. To overcome these problems, research about best distance learning tools and its implementation strategy is really needed. Therefore, this research aimed to analyze the strategies and tools for implementing distance learning that reliable and cost-effective for the student at the same time. Based on research that has been conducted by analyzing questionnaire surveys of 256 students in Indonesia, this research recommends tools combination strategy consists of Google Classroom tool as a learning app, Whatsapp group as broadcast messaging and Zoom as a video conference media for distance learning. This research also recommended to maximize the elearning/learning app features for theoretical lessons and consider video conference just in practical lessons so that the distance learning costs become cheaper for students.
\end{abstract}

\section{INTRODUCTION}

Pandemic COVID-19 has impacts various fields including education in the world. Various countries adopted a policy to change physical face-to-face teaching methods into distance learning to prevent the spread of a pandemic. Distance learning its self is learning process that allows instructors and students in different physical location [1]. In Indonesia, the distance learning policy is called "Belajar dari Rumah" (Learning from Home) contained in circular letter of the Indonesian Ministry of Education and Culture Number 701/LL7/AK/2020 [2].

Distance learning policy raises problem in Indonesia. The first problem is wide variety of tools that biased for students because student have to move between tools depending on what tool is used by an instructor on a subject [3]. This happen because the sudden distance learning policy, many educational institutions at various levels are not ready yet to apply distance learning [4] and letting instructors choose their respective tools such as Moodle, Google Classroom and Edmodo [5, 6]. The second problem is the raise complaints from students and instructors related to internet costs in conducting distance learning [7]. These problems, become important issues to implement distance learning in Indonesia.

The problems and issues on tools selection for distance learning and its implementation strategy have attracted various researchers in the world [8]. Research by Khajitpan in 2018 tried to analyze the needs of systems and telecommunications to implement distance learning. This research proposes a prototype called enhanced Telecom Operation Map (eTOM)
[9]. This prototype is claimed to be able to support videoconference learning through mobile and desktop devices. Another distance learning prototype was proposed by Artur, the prototype works by combining IT infrastructure and cloud infrastructure to deliver the service to any devices used by the student [10]. However, the implementation of the prototype requires more infrastructure devices and managements which is not cost-effective for educational institutions [11].

Research in cost-effective distance learning is then conducted by Kazuya. Kazuya proposed a remote class design based on low-cost computing infrastructure [12]. Kazuya's research utilizes the Internet network in general and uses Google Hangout tools as a video conference media. The results of the experiments conducted found that respondents had difficulty in following the learning process because of the limited audio and video quality [13]. This problem occurs because the remote class that is carried out still gathers students in one physical class and learns through one screen and speakers [12]. This reason also makes the method proposed by Kazuya doesn't suit for using in Indonesia during the pandemic, students need to learn for different locations.

Distance learning using free tools without infrastructure investment was carried out by Febrianti in 2017 [6] who tried to apply distance learning with Edmodo tools in Indonesia. This study found that students in Indonesia are not very active. There are two factors cause this, the first is limitation on internet access and the second is weak motivation for distance learning [6]. The lack of motivation can be caused by the absence of video conference interactions during the distance learning process between students and instructors [14]. 
The interaction between students and instructors is essential in distance learning [15]. Research by Titan proves that distance learning with active communication and instructors provides better results [16]. However, free tool that provide both online classroom and video conferencing features are still hard to find. Tools combination can be the solution to the case.

Research on tools combination for distance learning was conducted by Amer, this research proposed a distance learning system using Google Cloud Infrastructure [17]. There are several tools from Google that can be used for distance learning such as Google Hangout for video conferencing, Google Forms for quizzes, and Google Drive for content sharing. The results of this study concluded that Google Cloud Infrastructure can be used for distance learning. However, for special needs such as attendance, universities still have to make their own because they are not yet available by default on Google. Using cloud infrastructure as well, Laurynas carried out the use of Amazon Web Service (AWS) as a server to maintain stability and access for students [18]. Although this research's result claimed the proposed method can provide stable and flexible distance learning, the tools must still be developed by education institutions and also always need to be maintained.

Some researchers described previously shown that distance learning can be done with any tool that fulfills aspects of learning such as assignments, quizzes, discussions to face-toface meetings through video conferencing as shown in Figure 1 [16]. However, Indonesia has other aspects that must be considered such as the condition of Internet network infrastructure in terms of quality and costs [19]. So the tools used must be complete in terms of features and also have good quality on heterogeneous networks in terms of both speed and cost. The tools used for distance learning must also be easily implemented by educational institutions with minimal costs [20].

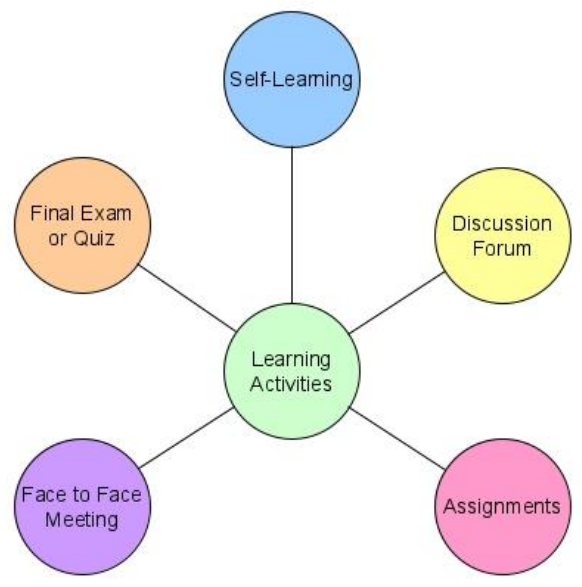

Figure 1. Learning activities [16]

This research aimed to formulate tools recommendation and implementation strategies for cost-effective distance learning that can be used by educational institutions so that all students can participate in learning well. The research conducted by analyzing questionnaire surveys of college students from various fields and regions in Indonesia on their experiences following distance learning during the COVID-19 pandemic. The results then become recommendation of tools and strategies for distance learning.

This paper is organized as follows. Section 2 explains the research method used. Section 3 explains the results of the analysis and findings from the data obtained. Finally, section 4 concludes this entire study.

\section{METHOD}

There are three main stages in this research, namely the develop survey questionnaire, data collection process and analysis of the survey results as show in Figure 2. The outcome of these stages is to obtain tools recommendations and costeffective implementation strategies for distance learning.

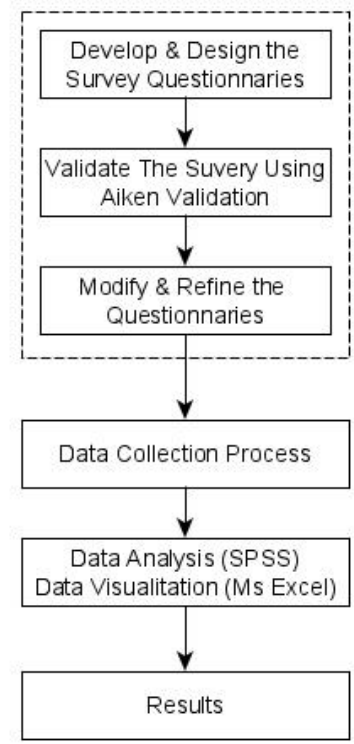

Figure 2. Research method flow

Each stage of the research can be described as follows:

\subsection{Develop \& design the survey questionnaire}

This research used two types of data instrument, the two instruments are open-ended and close-ended which both of them used as pre-requisite analysis of the main data. The first instrument is about quality and cost of internet access and the second instrument is about online learning tools used by students.

Each instrument used open questionnaire method for data collection of students' perception and opinions towards online learning. Contents of each instrument validated by Aiken which shows its number on 0.87 with 6 raters in language, technology, and education field. Meanwhile its test construct used SPSS STATISTIC 23 to find out the dimension which formed that the data came from the same factor / latent [21]. As the final two instruments used in this research can be described as follows:

\subsubsection{Survey content of internet and network access}

Infrastructure are one of the key factors of the success of distance learning [22]. Without internet infrastructure distance learning cannot be run [23]. Therefore, knowing the readiness of network infrastructure of students to access distance learning is really important [24], especially in developed or low-medium income country [25]. The expected outcome of this section is implementation strategy of distance learning that is cost-effective for students. As for the questions can be shown in Table 1 below: 
Table 1. Questions list about internet and network access

\begin{tabular}{cc}
\hline Code & Questions and Answer Choices \\
\hline PI-1 & What type of internet provider do you use? (Dedicated \\
& Internet/Mobile Data) \\
PI-2 & How is your current internet speed for distance learning? \\
& (Fast / Enough / Slow / Very Slow) \\
PI-3 & How much is the internet cost of the package / quota that \\
& you use to access distance learning each month? (< Rp. \\
& 50.000 / Rp. 50.000 - Rp. 100.000 / Rp. 100.000 - Rp. \\
& 200.000 / Rp. 200.000 - Rp. 300.000 / > Rp. 300.000) \\
PI-4 & Is that expensive for you? (Expensive / Inexpensive) \\
PI-5 & Is there a policy (free package / quota / free WIFI) to \\
& support distance learning? (Yes / No) \\
\hline
\end{tabular}

\subsubsection{Survey content of the use of online learning tools}

The second part of the survey questionnaire is intended to find out the use of distance learning tools used by students, instructors and universities. This survey part can give this research insight about reliable tools for distance learning and to ensure the technological skill both student and instructor, both are important for distance learning [26, 27]. At the end, recommendations of the best tools for distance learning in accordance with the conditions of Indonesia's can be suggested. As for the questions can be shown in Table 2 below:

Table 2. Questions list about distance learning tools

\begin{tabular}{|c|c|}
\hline Code & Questions and Answer Choices \\
\hline PT-1 & $\begin{array}{l}\text { Has the campus provided a good e-learning system? (Yes / } \\
\text { No) }\end{array}$ \\
\hline PT-2 & $\begin{array}{c}\text { If your campus' e-learning isn't good, what tools does your } \\
\text { lecturer usually use? (Google Classroom / Edmodo / } \\
\text { WhatsApp) }\end{array}$ \\
\hline PT-3 & $\begin{array}{c}\text { Are there lecturers who provide distance learning using } \\
\text { video conference? (Yes / No) }\end{array}$ \\
\hline PT-4 & $\begin{array}{l}\text { What tools do your lecturers usually use to hold online } \\
\text { classes in the form of video conference? (Zoom/Google } \\
\text { Meet) }\end{array}$ \\
\hline PT-5 & $\begin{array}{c}\text { As a support, what social media do you usually use for } \\
\text { class-related discussions? (WhatsApp / Telegram / } \\
\text { Instagram / Facebook) }\end{array}$ \\
\hline
\end{tabular}

\subsection{Data collection process}

Data collection in this study is carried out by distributing survey questionnaires that had been made previously to 256 college students in Indonesia randomly. These students have backgrounds from the exact, social and humanities. The distribution of the location itself is spread in various regions in Indonesia.

The data is collected within one week between April 6, 2020 and April 12, 2020. When this data is collected, Indonesia has implemented a distance learning policy so that all respondents are students who have experience in conducting distance learning.

\subsection{Survey result analysis}

The Analysis of the survey results is done by calculating the percentage of the answers to each survey question using Equation 1. This is the same method that used by Kazuya [12] to analyze survey data. The main factor why this research use Kazuya method [12] is because its simplicity and accurate result.

$$
\text { Percentage }(\%)=\frac{x}{n} \times 100 \%
$$

In this equation, $x$ represents the total number of samples that chose an answer and $n$ is the total sample. This research conducts the calculation for each of question in the survey. SPSS is used to calculate the result and Ms. Excel is used for visualization. The results are then further analyzed to determine the correlation of answers. In the end, the results analysis can provide knowledge about tools and strategies for implementing distance learning in Indonesia.

\section{RESULTS AND DISCUSSION}

The results of this study are divided into three part. The first part is the results of surveys related to internet network infrastructure support, the second part is the results of distance learning survey tools and the last is recommendations proposed by this research for distance learning:

\subsection{Results of internet access support survey}

\subsubsection{PI-1: Types of students' internet provider}

The survey results related to the types of internet providers used by students to attend distance learning is shown in Table 3 and Figure 3 below:

Table 3. Detail result of type of student internet provider

\begin{tabular}{cccc}
\hline Answer & Frequency & Percent & $\begin{array}{c}\text { Cumulative } \\
\text { Percent }\end{array}$ \\
\hline Mobile Data & 21 & $8.2 \%$ & $8.2 \%$ \\
\hline Dedicated Internet & 235 & $91.8 \%$ & $100.0 \%$ \\
\hline Total & 256 & $100.0 \%$ & \\
\hline
\end{tabular}

\section{Type of Student's Internet Provider (\%)}

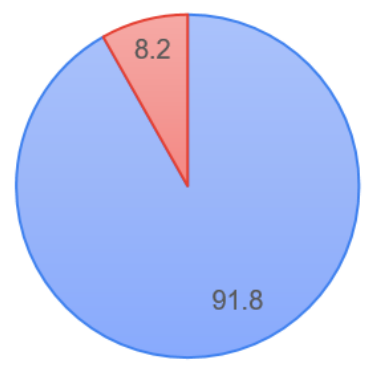

$\square$ Mobile Data $\quad$ DDedicated Internet

Figure 3. Types of students' internet provider in Indonesia

Table 3 and Figure 3 above show that students in Indonesia basically have internet access. However, $91.8 \%$ of the students still access the internet via mobile data, compared to only $8.20 \%$ who have access to the dedicated internet. This makes the internet access speed at $91.80 \%$ of the students is still unstable and costly.

\subsubsection{PI-2: Students' internet speed}

The survey results related to the students' internet speed to access distance learning are shown in Table 4 and Figure 4 below: 
Table 4. Detail result of student' internet speed

\begin{tabular}{cccc}
\hline Answer & Frequency & Percent & Cumulative Percent \\
\hline Fast & 43 & $16.8 \%$ & $16.8 \%$ \\
Sufficient & 173 & $67.6 \%$ & $84.4 \%$ \\
Slow & 31 & $12.1 \%$ & $96.5 \%$ \\
Really Slow & 9 & $3.5 \%$ & $100.0 \%$ \\
Total & 256 & $100.0 \%$ & \\
\hline
\end{tabular}

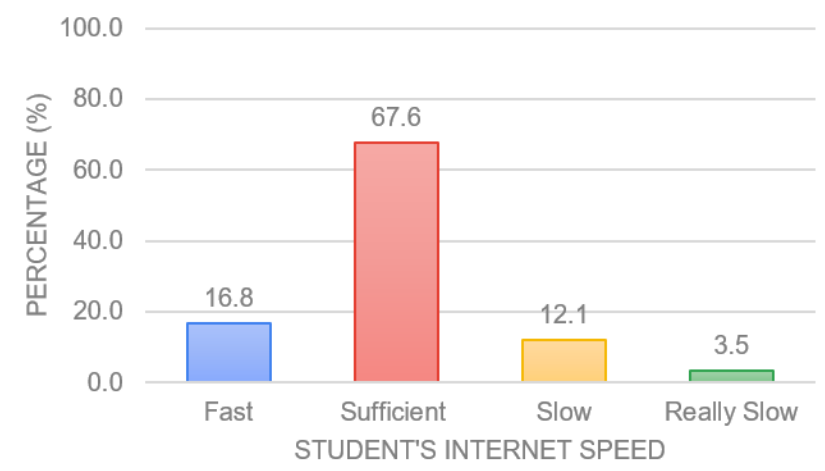

Figure 4. Students' internet speed in Indonesia

Table 4 and Figure 4 show that only $16.8 \%$ of students have fast internet speeds, while $67.6 \%$ have sufficient internet access speed for distance learning. However, $12.1 \%$ of students have slow internet speeds for distance learning. Even $3.52 \%$ of Indonesian students still have very slow internet access. This result shows that student will experience difficulty in face-to-face explanations through video conference.

\subsubsection{PI-3: Students' internet access costs}

During distance learning, students spend additional costs for internet access. The amount of these additional costs varies between students as shown in Table 5 and Figure 5 below:

Table 5. Detail result of student' internet costs

\begin{tabular}{|c|c|c|c|}
\hline Answer & Frequency & Percent & Cumulative Percent \\
\hline$<$ Rp.50.000 & 9 & $3.5 \%$ & $3.5 \%$ \\
\hline $\begin{array}{l}\text { Rp.50.000- } \\
\text { Rp.100.000 }\end{array}$ & 156 & $60.9 \%$ & $64.4 \%$ \\
\hline $\begin{array}{l}\text { Rp.100.000- } \\
\text { Rp.200.000 }\end{array}$ & 73 & $28.5 \%$ & $92.9 \%$ \\
\hline $\begin{array}{l}\text { Rp.200.000- } \\
\text { Rp.300.000 }\end{array}$ & 11 & $4.3 \%$ & $97.2 \%$ \\
\hline $\begin{array}{c}>\text { Rp. } 300.000 \\
\text { Total }\end{array}$ & $\begin{array}{c}7 \\
256\end{array}$ & $\begin{array}{c}2.7 \% \\
100.0 \%\end{array}$ & $100.0 \%$ \\
\hline
\end{tabular}

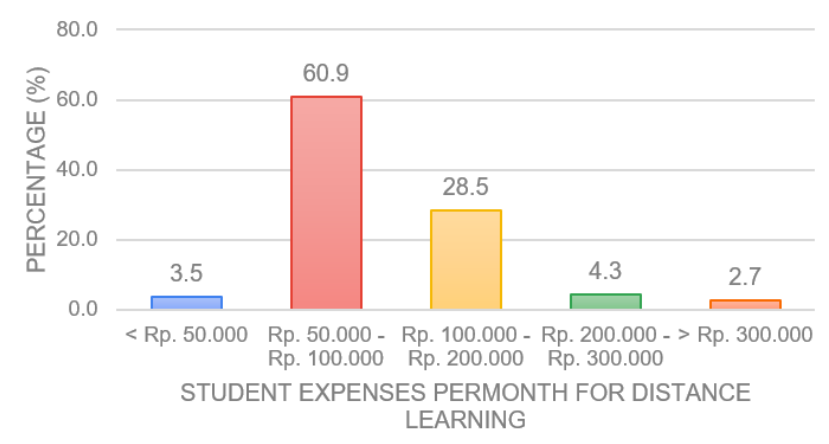

Figure 5. Additional cost per month that students' spend for internet access during distance learning
Table 5 and Figure 5 show that $60.9 \%$ of students must spend additional cost of around Rp.50,000 - Rp. 100,000 for internet access. Meanwhile there are $28.52 \%$ which must spend additional cost for around Rp.100,000 - Rp. 200,000 and 7.03\% spend more than Rp. 200,000 on Internet access during distance learning. The amount of these additional costs is classified as a large amount for students. The amount of this cost can increase if there are more classes with video conference.

3.1.4 PI-4: Whether or not expensive: The cost of online learning

The survey related to the expensiveness of additional cost for internet access during online learning is shown in Table 6 and Figure 6 below:

Table 6. Detail result of expensiveness of internet cost

\begin{tabular}{cccc}
\hline Answer & Frequency & Percent & Cumulative Percent \\
\hline Expensive & 231 & $90.2 \%$ & $90.2 \%$ \\
Not Expensive & 25 & $9.8 \%$ & $100.0 \%$ \\
Total & 256 & $100.0 \%$ & \\
\hline
\end{tabular}

Students Find Distance Learning is Expensive

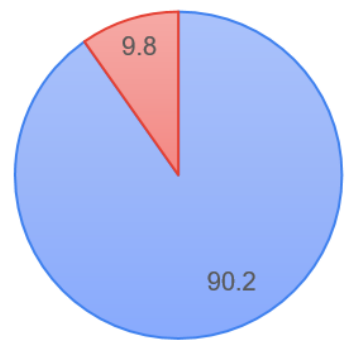

口Expensive $\quad$ Not Expensive

Figure 6. Whether or not expensive: The cost of online learning for students

The survey results show that $90.2 \%$ of distance learning students felt that the additional expenditure is expensive and only $9.77 \%$ thought that the expenditure is inexpensive. This result shows that policy action is needed in the form of subsidies and others related to the cost of internet access for distance learning so that students can continue to follow the lessons.

\subsubsection{PI-5: Internet facility policy for students}

Table 7 and Figure 7 shows the results of the survey related to internet facilities support for students. It is seen that $96.1 \%$ of students who have to take distance learning do not get any assistance or facilities related to additional expense for the Internet during distance learning. If it is left unchecked, this can result in a decrease in the number of student participation [28].

Table 7. Detail result of internet facility policy for student

\begin{tabular}{cccc}
\hline Answer & Frequency & Percent & $\begin{array}{c}\text { Cumulative } \\
\text { Percent }\end{array}$ \\
\hline Get Assistance & 10 & $3.9 \%$ & $3.9 \%$ \\
No Assistance & 246 & $96.1 \%$ & $100.0 \%$ \\
Total & 256 & $100.0 \%$ & \\
\hline
\end{tabular}




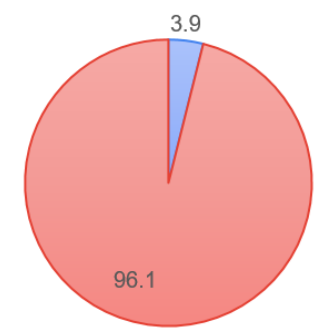

口Get Assistance $\quad$ No Assistance

Figure 7. Support in internet access for students

\subsection{Results of the distance learning tools survey}

Distance learning is not run only with fast and easy Internet access but also the tools used. The following survey results are related to distance learning tools that used by the students during pandemic:

\subsubsection{PT-1: Students' satisfaction in campus' E-learning}

Universities in Indonesia mostly have Moodle-based elearning. The role of e-learning is vital in distance learning. The survey regarding the level of satisfaction using e-learning is shown in Table 8 and Figure 8 below:

Table 8. Detail result of satisfaction in campus' e-learning

\begin{tabular}{cccc}
\hline Answer & Frequency & Percent & Cumulative Percent \\
\hline Satisfied & 121 & $47.3 \%$ & $47.3 \%$ \\
Not Satisfied & 135 & $52.7 \%$ & $100.0 \%$ \\
Total & 256 & $100.0 \%$ & \\
\hline
\end{tabular}

Student's Satisfaction with University E- Learning

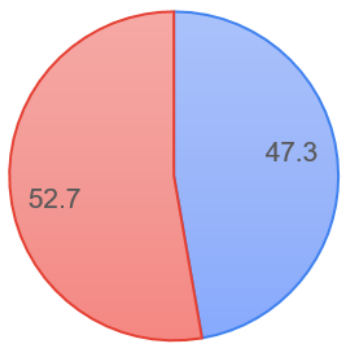

口Satisfied aNot Satisfied

Figure 8. Students' satisfaction in campus' e-learning

Figure 8 above show $52.7 \%$ of students are not satisfied with e-learning that is used on their campuses. Only $47.3 \%$ are satisfied. These results indicate the use of campus's e-learning in Indonesia still needs further socialization and development. However, this can be overcome by using other tools such as Google Classroom and Edmodo. The use of these tools is quite high even though the campus has provided its own e-learning as shown in Section PT-2.

3.2.2 PT-2: Tools used instead of universities' E-learning

The survey shows that although the campus has provided elearning, many instructors still use other tools to deliver distance learning. The tools used are shown below:
Table 9. Variety of apps used by students for distance learning

\begin{tabular}{ccccccc}
\hline \multirow{2}{*}{ Answer } & \multicolumn{2}{c}{ Google Classroom } & \multicolumn{2}{c}{ Edmodo } & \multicolumn{2}{c}{ WhatsApp } \\
\cline { 2 - 7 } & Freq. & \% & Freq. & \% & Freq. & \% \\
\hline Using & 190 & 74.2 & 49 & 19.1 & 103 & 40.2 \\
Not Using & 66 & 25.8 & 207 & 80.9 & 153 & 59.8 \\
Total & 256 & 100.0 & 256 & 100.0 & 256 & 100.0 \\
\hline
\end{tabular}

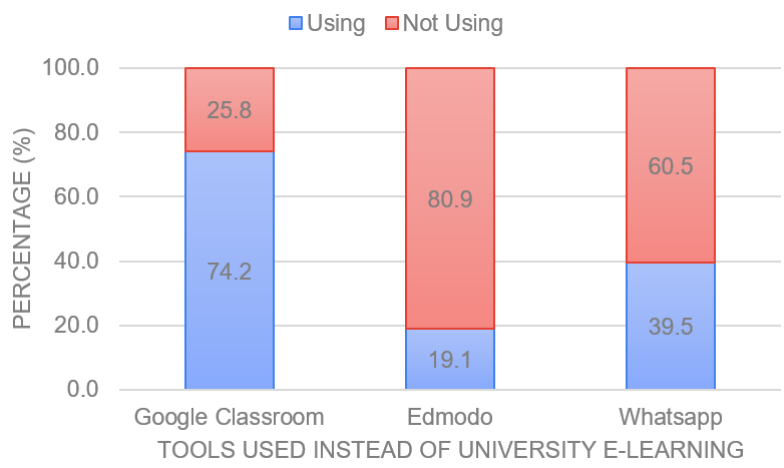

Figure 9. Tools used instead of universities' e-learning

Based on Table 9 and Figure 9 above, it can be seen that although the campus in Indonesia has prepared e-learning, other tools are still used by instructors to support distance learning. The result shows that $74.2 \%$ out of $100 \%$ of distances learning students use Google Classroom tools. While the use of Edmodo reaches $19.14 \%$ out of $100 \%$ of students also use and there are $39.45 \%$ out of $100 \%$ of students also use WhatsApp as a medium of distance learning.

There are two interesting things found from the result. First, students can use several tools for online learning, there are even students who use all three, namely Google Classroom, Edmodo and WhatsApp. Second, surprisingly WhatsApp, which is an instant messaging app-based social media [29] and is not intended specifically for learning app, is apparently quite widely used to convey distance learning. These results indicate that the distance teaching process in Indonesia is very flexible.

\subsubsection{PT-3: The use of video conference}

Face-to-face meetings on distance learning can be done through video conferencing media. The implementation of teaching with video conferencing in Indonesia can be seen through the following Table 10 and Figure 10 below:

Table 10. Detail result of distance learning using video conference

\begin{tabular}{cccc}
\hline Answer & Frequency & Percent & Cumulative Percent \\
\hline $\begin{array}{c}\text { Using Video } \\
\text { Conference }\end{array}$ & 229 & $89.5 \%$ & $89.5 \%$ \\
$\begin{array}{c}\text { Not Using Video } \\
\text { Conference } \\
\text { Total }\end{array}$ & 27 & $10.5 \%$ & $100.0 \%$ \\
\hline
\end{tabular}

The result shows $89.45 \%$ of students have use video conference and only $10.55 \%$ have never use video conference. Survey results show that Indonesian distance learning mostly fulfills good distance learning requirements [30]. 


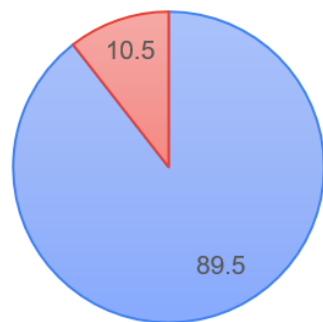

口Using Video Conference $\quad$ №t Using Video Conference

Figure 10. Percentage of video conference learning

\subsubsection{PT-4: Video conference tools}

Following are the results of a survey related to video conference (vicon) tools used in Indonesia:

Table 11. Detail result of tools for video conference

\begin{tabular}{cccc}
\hline Answer & Frequency & Percent & Cumulative Percent \\
\hline Zoom & 210 & $82.0 \%$ & $82.0 \%$ \\
Google Meet & 19 & $7.4 \%$ & $89.4 \%$ \\
No Vicon & 27 & $10.5 \%$ & $100.0 \%$ \\
Total & 256 & $100.0 \%$ & \\
\hline
\end{tabular}

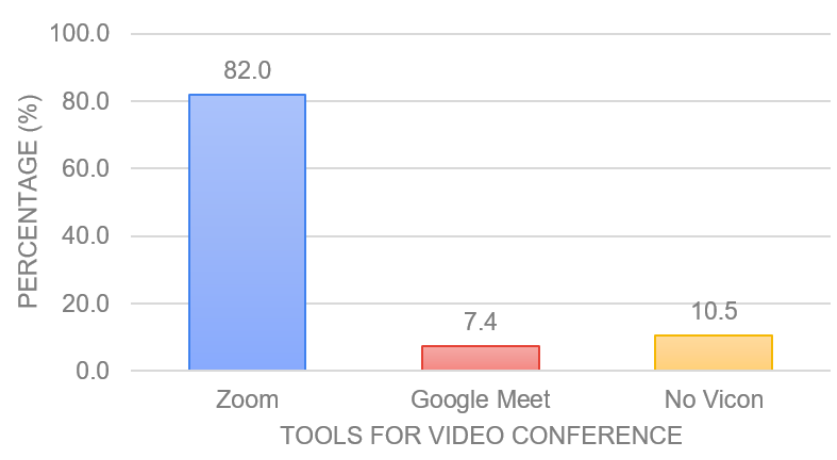

Figure 11. Tools used for video conference

Table 11 and Figure 11 show that the most widely used tool for video conference in Indonesia for distance learning is Zoom with $82.03 \%$, followed by Google Meet with $7.42 \%$, while $10.55 \%$ of students do not use video conference at all.

\subsubsection{PT-5: Social media as learning support}

In addition to learning tools, distance learning in Indonesia also utilizes social media for information dissemination. The most widely used social media is shown as Table 12 .

Table 12. Detail result of social media as learning support

\begin{tabular}{cccc}
\hline Answer & Frequency & Percent & Cumulative Percent \\
\hline WhatsApp & 251 & $98.0 \%$ & $98.0 \%$ \\
Facebook & 1 & $0.4 \%$ & $98.4 \%$ \\
Telegram & 2 & $0.8 \%$ & $99.2 \%$ \\
Instagram & 2 & $0.8 \%$ & $100 \%$ \\
Total & 256 & $100.0 \%$ & \\
\hline
\end{tabular}

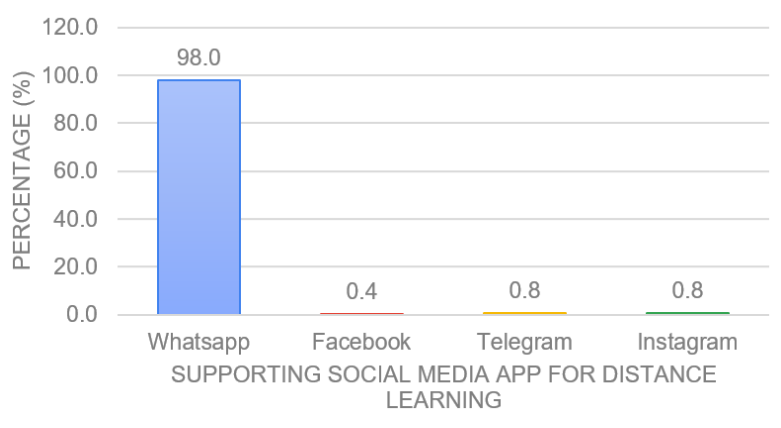

Figure 12. Social media used to support distance learning

Figure 12 shows that WhatsApp as social media based on instant messaging became the most widely used application to spread information related to distance learning during the COVID-19 pandemic in Indonesia with $98.05 \%$ of respondents. The simplicity and speed factor make WhatsApp more widely used than other social media like Facebook, Telegram and Instagram, which do not show a significant contribution to the dissemination of learning information.

\subsection{Recommendation}

Based on the survey that has been conducted, this research recommends using tools combination for distance learning. This recommendation is based on this research survey result which show that there is no single tool that can fulfill all distance learning needs (assignments, quizzes, discussions, face-to-face meeting etc. [16]).

The tools combination proposed are Google Classroom as learning app, WhatsApp as broadcast instant messaging and Zoom as video conferencing media as seen in Figure 13. This research recommends Google Classroom as learning app based on the survey result where $74.2 \%$ student in Indonesia use it, even when their university already have its own elearning. This shows that Google Classroom is easier to use and stable in Indonesia. Google Classroom is also having features to meet learning criteria tools such as assignment, quiz and exam feature [16]. However, based on our analysis, Google Classroom is not really good to facilitate forum discussion, this is why student need social media like WhatsApp to communicate.

This research suggested WhatsApp as messaging tools to send broadcast message, give announcement or discuss learning material for distance learning. This suggestion is based on the survey result which show that $98.1 \%$ of Indonesia students used to support distance learning. The last app for distance learning especially for face to face meeting that this research suggest is Zoom. Zoom is suggested based in survey results which show that $82 \%$ of Indonesian student use it. This result show that Zoom can be work stably in Indonesia.

This research also recommends implementation strategy for distance learning that cost-effective for student. The suggested implementation strategies are minimizing the use video conference in theory subject and consider to use it just in practicum subjects. This recommendation is based on research result which find that $90.2 \%$ of Indonesian student find distance learning is expensive, this can cause a lot of student stop to follow the distance learning. To reduce the cost, video conference that takes up a lot of internet quota [31] of the student should be reduce and only be used in important meeting or in practicum subject. 


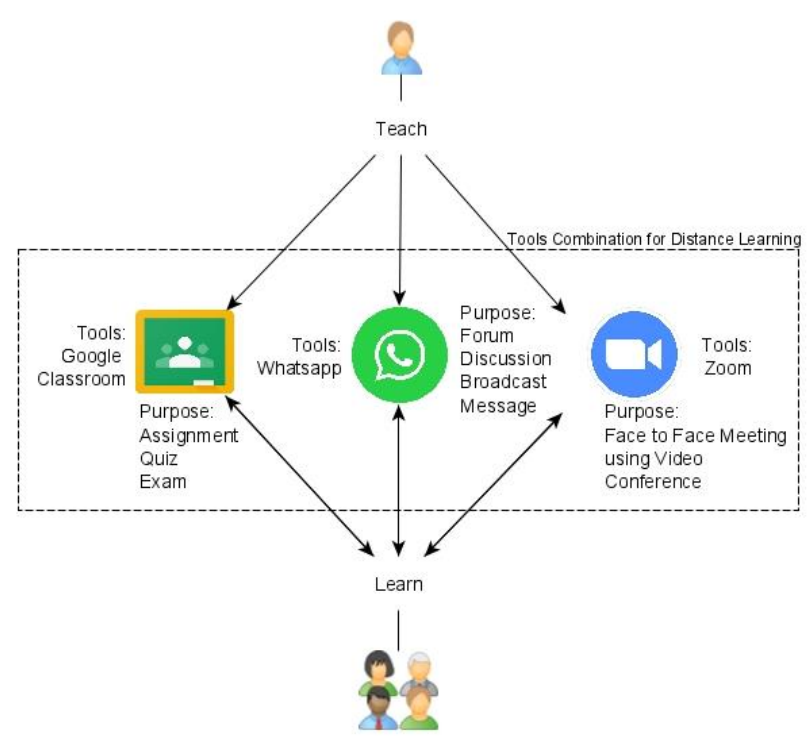

Figure 13. Recommendation of tools combination for distance learning

\section{CONCLUSIONS}

Tools and implementation strategies are very important factors for distance learning during the COVID-19 pandemic, especially for educational institutions and students with heterogeneous infrastructure and internet access like in Indonesia. Cost-effective and efficient tool and strategy are needed. In this study, tools and implementation strategies for cost-effective and efficient distance learning are proposed.

The tools combination of Google Classroom, WhatsApp and Zoom is the best choice for distance learning. All three applications can be used together with different designations. Google Classroom is used as a learning app for quizzes and assignments. WhatsApp group can be used as broadcast instant messaging as well as student discussion forums tools and Zoom is used for face-to-face via video conferencing.

For the distance learning implementation strategy this paper recommends self-learning methods utilizing the features available in Google Classroom for theoretical lessons and consider face-to-face meeting for video conference only in important and practicum subject. With tools and strategies suggested, students' internet usage will be efficient so that online learning cost becomes cheaper for student.

\section{REFERENCES}

[1] Widyaningrum, H. K., Hasanudin, C., Fitrianingsih, A., Novianti, D.E., Saddhono, K., Supratmi, N. (2020). The use of Edmodo apps in flipped classroom learning. How is the students' creative thinking ability? Ingénierie des Systèmes d'Information, 25(1): 69-74. https://doi.org/10.18280/isi.250109

[2] Indonesian Ministry of Education and Culture (Kemdikbud). (2020). SE Mendikbud: Pembelajaran secara Daring dan Bekerja dari Rumah untuk Mencegah Penyebaran

COVID-19. http://kemdikbud.go.id/main/files/download/c5d9f0ec9f f40c6.

[3] Bobokhujaev, S.I. (2019). The role of ICT and the problems of organizing distance education in Uzbekistan.
2019 International Conference on Information Science and Communications Technologies (ICISCT), Tashkent, Uzbekistan $\mathrm{pp}$ 1-4. https://doi.org/10.1109/ICISCT47635.2019.9011876

[4] Abu, A., Jusmawati, J., Makmur, Z., Jumliadi, J., Yusuf, M. (2020). Problems Faced by IAIN Palu Students in Online Learning in the Middle of the COVID-19 Pandemic. International Colloquium on Environmental Education (ICEE). Available: https://www.researchgate.net/publication/342601280

[5] Nadeak, B. (2020). The effectiveness of distance learning using social media during the pandemic period of COVID-19: A case in Universitas Kristen Indonesia. International Journal of Advanced Science and Technology, 29(7): 1764-1772.

[6] Widyahastuti, F., Fransiskus, D., Tjhin, V.U. (2017). How active are K-12 students using Edmodo as online motivation, interaction and collaboration tools for learning process? 10th International Conference on Human System Interactions, HSI 2017, Ulsan, South Korea, pp. 94-97. https://doi.org/10.1109/HSI.2017.8005005

[7] Hasani, L.M., Adnan, H.R. (2020). Factors affecting student's perceived readiness on abrupt distance learning adoption: Indonesian Higher-Education Perspectives. Research Gate. https://doi.org/10.13140/RG.2.2.22908.16008

[8] Panigrahi, R., Srivastava, P.R., Sharma, D. (2018). Online learning: Adoption, continuance, and learning outcome: A review of literature. International Journal of Information Management, 4: 1-14. https://doi.org/10.1016/j.ijinfomgt.2018.05.005

[9] Kritpolviman, K.M. (2018). Analysis of equipment systems, tools, and telecommunication engineering management for supporting distance learning systems via electronic media, Sukhothai Thammathirat open university: System prototype and implementation. 2018 15th International Conference on Electrical Engineering/Electronics, Computer, Telecommunications and Information Technology (ECTI-CON), Chiang Rai, Thailand, pp. 142-145. https://doi.org/10.1109/ECTICon.2018.8620038

[10] Rot, A., Chrobak, P., Sobinska, M. (2019). Optimisation of the Use of IT Infrastructure Resources in an Institution of higher education: A case study. 2019 9th International Conference on Advanced Computer Information Technologies (ACIT), Ceske Budejovice, Czech Republic, pp. 171-174. https://doi.org/10.1109/ACITT.2019.8780018

[11] Utomo, M.N.Y., Bastian, A., Winursito, A. (2020). Improving speed performance of select random query in SQL database. Intek: Jurnal Penelitian, 7(1): 26-31. https://doi.org/10.31963/intek.v7i1.1536

[12] Murata, K. (2019). Design of interactive remote class environment by infrastructure-based low-cost computing. 8th International Congress on Advanced Applied Informatics 2019, pp. 948-953. https://doi.org/10.1109/IIAI-AAI.2019.00190

[13] Winursito, A., Hidayat, R., Bejo, A., Utomo, M.N.Y. (2018). Feature data reduction of MFCC Using PCA and SVD in speech recognition system. 2018 International Conference on Smart Computing and Electronic Enterprise (ICSCEE), Shah Alam, Malaysia, pp. 1-6. https://doi.org/10.1109/ICSCEE.2018.8538414 
[14] Burdina, G.M., Krapotkina, I.E., Nasyrova, L.G. (2019). Distance learning in elementary school classrooms: An emerging framework for contemporary practice. International Journal of Instruction, 12(1): 1-16. https://doi.org/10.29333/iji.2019.1211a

[15] Wang, S., Minku, L.L., Yao, X. (2018). A systematic study of online class imbalance learning with concept drift. IEEE Transactions on Neural Networks and Learning Systems, 29(10): 4802-4821. https://doi.org/10.1109/TNNLS.2017.2771290

[16] Ferdianto, T., Faniru Pakuning Desak, G.G., Lena. (2018). A Comparative Study of Teaching Styles in Online Learning Environment. International Conference on Information Management and Technology, ICIMTech 2017, Yogyakarta, Indonesia, pp. 25-30. https://doi.org/10.1109/ICIMTech.2017.8273505

[17] Hasanović, A., Mujčić, A., Suljanović, N., Pjanić, E., Samuelsen, D., Thyberg, B., Graven, O.H. (2012). Improving higher education with the cloud infrastructure: Information system requirements analysis for a modern global university. 2012 15th International Conference on Interactive Collaborative Learning (ICL), Villach, Austria, pp. 1-3 https://doi.org/10.1109/ICL.2012.6402154

[18] Riliskis, L., Osipov, E. (2013). Coexistence of cloud technology and IT infrastructure in higher education. Frontiers in Education Conference, FIE, Oklahoma City, OK, USA, pp. 805-807. https://doi.org/10.1109/FIE.2013.6684937

[19] Utomo, M.N.Y., Permanasari, A.E., Tungadi, E., Syamsuddin, I. (2017). Determining single tuition fee of higher education in Indonesia: A comparative analysis of data mining classification algorithms. 4th International Conference on New Media Studies, Yogyakarta, Indonesia, pp. 113-117. https://doi.org/10.1109/CONMEDIA.2017.8266041

[20] Valyavsky, A.Y., Ivanov, M.N., Uchevatkina, N.V. (2020). Features of financial support of the educational process with the use of E-learning and distance learning technologies. The International Scientific Conference "Far East Con" (ISCFEC 2020), pp. 3089-3095. https://doi.org/10.2991/aebmr.k.200312.442

[21] Sudaryanto, M., Mardapi, D., Hadi, S. (2019). Multimedia-based online test on Indonesian language receptive skills development. Journal of Physics: Conference $\quad$ Series, $1339(1)$ : 1-7. https://doi.org/10.1088/1742-6596/1339/1/012120

[22] Hillier, M. (2018). Bridging the digital divide with offline e-learning. Distance Education, 39(1): 110-121. https://doi.org/10.1080/01587919.2017.1418627
[23] Aldholay, A.H., Abdullah, Z., Ramayah, T., Isaac, O., Mutahar, A.M. (2018). Online learning usage and performance among students within public universities in Yemen. International Journal of Services and Standards (IJSS), 12(2): 163-179. https://doi.org/10.1504/IJSS.2018.10012964

[24] Leontyeva, I.A. (2018). Modern distance learning technologies in higher education: Introduction problems. Eurasia Journal of Mathematics, Science and Technology Education, 14(10): 1-8. https://doi.org/10.29333/ejmste/92284

[25] Palvia, S., Aeron, P., Gupta, P., Mahapartra, D., Parida, R., Rosner, R. (2018). Online Education: Worldwide Status, Challenges, Trends, and Implications. Journal of Global Information Technology Management, 21(4): 233-241. https://doi.org/10.1080/1097198X.2018.1542262

[26] Beskrovnaya, V.A., Freidkina, E.M., Vinogradova, T.I. (2019). Approaches to assessing the quality of distance learning in higher education through the development of tools for monitoring learning outcomes. International Scientific and Practical Conference on Digital Economy (ISCDE 2019), pp. 716-721. https://doi.org/10.2991/iscde-19.2019.139

[27] O’Doherty, D., Dromey, M., Lougheed, J., Hannigan, A., Last, J., McGrath, D. (2018). Barriers and solutions to online learning in medical education - an integrative review. BMC Medical Education, 20(22): 832-834. https://doi.org/10.1186/s12909-018-1240-0

[28] Gregori, P., Martínez, V., Moyano-Fernández, J.J. (2018). Basic actions to reduce dropout rates in distance learning. Evaluation and Program Planning, 66(7): 48-52. https://doi.org/10.1016/j.evalprogplan.2017.10.004

[29] Utomo, M.N.Y., Adji, T.B., Ardiyanto, I. (2018). Geolocation prediction in social media data using text analysis: A review. International Conference on Information and Communications Technology, ICOIACT 2018, Yogyakarta, Indonesia, pp. 84-89. https://doi.org/10.1109/ICOIACT.2018.8350674

[30] Shakhovska, N., Vysotska, V., Chyrun, L. (2017). Intelligent systems design of distance learning realization for modern youth promotion and involvement in independent scientific researches. Advances in Intelligent Systems and Computing, 512(1): 175-198. https://doi.org/10.1007/978-3-319-45991-2

[31] Rush, K.L., Howlett, L., Munro, A., Burton, L. (2018). Videoconference compared to telephone in healthcare delivery: A systematic review. International Journal of Medical Informatics, 118: 44-53. https://doi.org/10.1016/j.ijmedinf.2018.07.007 